\title{
AN OUTLINE OF THE HISTORY OF CLASSICAL PHILOLOGY AT THE JAGIELLONIAN UNIVERSITY
}

ABSTRACT: This paper aims to familiarize contemporary students and scholars of classical philology with the profiles of prominent Polish classical philologists related to the Jagiellonian University in Kraków. It contains biographical notes and description of works of most important classicists at the Jagiellonian University, who lived in the $19^{\text {th }}$ and in the $20^{\text {th }}$ century. The scholars presented in the article are: Kazimierz Morawski, Tadeusz Sinko, Seweryn Hammer, Leon Sternbach, Wincenty Lutosławski, Ryszard Gansiniec, Stanisław Skimina, Władysław Madyda, Romuald Turasiewicz, Adam Stefan Miodoński, Gustaw Edward Przychocki, Władysław Strzelecki, Kazimierz Kumaniecki, Mieczysław Brożek, Marian Plezia, Kazimierz Korus, Józef Korpanty and Stanisław Stabryła.

KEY WORDS: history of classical scholarship, classical philology, Jagiellonian University

Research on classical antiquity at the Jagiellonian University dates back to the $15^{\text {th }}$ century and has been inseparably intertwined with humanism. The desire to promote classical studies among the younger generation as a discipline that permeates all other scholarly fields was great among scholars already at the beginning of the Kraków university. Numerous lecturers were active at the university in the Middle Ages, the Renaissance and later, mostly teaching Latin and Greek, but also devoting their energy to editing ancient texts or translating them into Polish. For a long 
time the Jagiellonian University was to remain the easternmost university offering such education opportunities. ${ }^{1}$ Of course the two departments, i.e. Greek and Latin studies, developed at different paces throughout the centuries. Latin culture, brought to Poland with the Renaissance of the $15^{\text {th }}$ and $16^{\text {th }}$ century, was a fundamental and crucial element of education until the very end of the republic of nobles. The Greek studies department initially attempted to teach about the more notable Hellenistic authors or the grammar of the language.

Texts of ancient authors were among the interests of the University professors practically from the beginning. The people who influenced classics at the beginning of the Jagiellonian University were, among others, Jan Elgot, the rector of the University of Kraków in 1427 and 1437, well-versed in classical Latin, as well as Grzegorz of Sanok (1406-1477), a great promoter of classical culture, who taught lectures about the Eclogues of Virgil, the Polish-Latin poet Paweł of Krosno (ca. 1470-1517), and Stanisław Grzepski (1524-1570), the most laudable Hellenist of the $16^{\text {th }}$ century, who explained in his lectures the works of authors such as Sophocles, Euripides, Herodotus and Pindar. $^{2}$ A person who made a significant contribution to classical studies was Jakub Górski (1525-1585), interested mainly in ancient rhetoric, especially in the works of Cicero. Dubbed the greatest classical philologist of the Renaissance, Andrzej Patrycy Nidecki (1522-1586), ${ }^{3}$ who considered Nowopolczyk and Marycjusz from the University of Kraków masters of his early education, published Cicero's works in Poland. ${ }^{4}$ In the $17^{\text {th }}$ and $18^{\text {th }}$ centuries, classical studies were in a rather difficult situation. It was due to a general decline in education, especially in middle schools, and a series of PolishSwedish wars in the $17^{\text {th }}$ century. ${ }^{5}$ As a special reason, one can regard the sending of the best scholars from the Jagiellonian University to the Zamojski Academy in Zamość, but this new ambitious educational project would later fail in the long run. ${ }^{6}$ That was the beginning of the fall, but the situation deteriorated even further in the $18^{\text {th }}$ century, when Latin

Gruchała 2000: 13-14.

Gruchała 2000: 26.

Hammer 1948: 6-12; Plezia 1993: 5-10; Sondel 2012: 394-399.

Gruchała 2000: 17.

Plezia 1966: 66.

Plezia 1966: 66. 
was treated as another foreign language of practical application and the knowledge of Greek was rare. ${ }^{7}$ A revival was marked by the earliest works of Kazimierz Morawski (1852-1925), whose scholarly output is described below in a separate section.

In an attempt to describe the history of classical studies at the Jagiellonian University, its two aspects must be taken into consideration, namely the Greek language and literature, on the one hand, and the Latin language and literature, on the other. It is, however, not easy to discern between those two areas, primarily due to the fact that the individual classicists in Kraków were interested and engaged in both. This difficulty is first and foremost indicative of excellent competence on the part of the above-mentioned historians of classical literature. Moreover, it testifies to their utter commitment and devotion to research on classical antiquity, which was remarkably comprehensive and comprised a vast cultural context. In most cases, however, the scholars presented in this article have been divided into Hellenists and Latinists, although occasionally it was impossible to ascribe a scholar to one field due to his equally extensive research in both areas. This is the case with people such as Kazimierz Morawski, the father of classical studies at the Jagiellonian University, Tadeusz Sinko, and Seweryn Hammer, each of whom deserves to be classified beyond these two categories.

\section{"THE RENAISSANCE OF CLASSICAL PHILOLOGY"- KAZIMIERZ MORAWSKI}

In the sense of a modern academic discipline, classical philology crystallized in the second half of $19^{\text {th }}$ century, when Kazimierz Morawski (1852-1925) first came to Kraków. ${ }^{8}$ It is he that led classical studies in Poland to prosperity and helped the discipline achieve the international level. ${ }^{9}$ After passing his secondary school exit examinations, Morawski enrolled in a course in philosophy at the Faculty of Philosophy of the University of Berlin, to eventually receive Ph.D. for his Latin disserta-

Plezia 1966: 71-73.

$8 \quad$ Plezia 1993: 8.

9 Madyda 1964: 53. 
tion Quaestiones Quintilianeae (1874). ${ }^{10}$ Having finished his teaching practice at a secondary school in Wrocław (1875/76), he devoted himself to academic work in Kraków, focusing on the works of Greek and Roman orators. ${ }^{11}$ He passed his post-doctoral examination in 1877, soon after returning from a five-month academic stay in Italy. ${ }^{12}$ Although he had not had a large academic output at that time, as a 26-year-old with an appointment equivalent to associate professor was considered to be very promising by the academia. His contributions to the development of the Jagiellonian University over the years proved that he did not dash those hopes. In his studies, he focused on classical rhetoric and its impact on the authors in the period of the Roman Empire. ${ }^{13} \mathrm{~A}$ "scholar of European stature", ${ }^{14}$ his works include dozens of specialist publications, which appeared both in Poland and internationally, not to mention those pertaining to popular science. ${ }^{15}$ The crowning achievement of his literary career was Historia literatury rzymskiej [The History of Roman Literature] published in seven volumes over the years 1909-1921. However, what made him truly renowned was the position of a lecturer, where he proved to be a natural-born speaker. ${ }^{16}$ The majority of his lectures were devoted to Roman literature, but he also authored numerous monographs, and conducted lectures on Greek literature and Latin historical and descriptive grammar. He was acclaimed by his students not only for his vast knowledge, which he shared so skilfully and expressively, but also for his extensive engagement, resulting from his deep understanding of his teaching mission. His conviction of the didactic value of culture gave rise to next generations of classical philologists with patriotic hearts whose Polish character exhibited both Roman and Greek fortitude. ${ }^{17}$

\footnotetext{
10 Korus 2000a: 118.

11 Hammer 1948: 28.

12 Korus 2000a: 119.

13 Hammer 1948: 29.

14 Hammer 1948: 31.

15 Hammer 1948: 31-32.

16 Madyda 1964: 53-54.

17 Plezia 1993: 142.
} 


\section{RESEARCHERS IN BOTH FIELDS - TADEUSZ SINKO AND SEWERYN HAMMER}

The most prolific and versatile disciple of Morawski, as well as Miodoński and Sternbach (whose output will be presented in the following subsections), was undoubtedly Tadeusz Sinko (1877-1966), considered the "greatest classical philologist and humanist in the history of Polish culture". ${ }^{18}$ In the course of his 50-year activity at the Jagiellonian University, he raised "hundreds (sic!) of philologists, properly prepared for the teaching profession. His bibliography consists of a total of 787 items, not including his newspaper columns or book reviews". ${ }^{19}$ Having received his Ph.D. in 1900, he continued his studies in Berlin. As a scholarship holder, he conducted research in libraries of Paris, Rome, Florence, Venice and Milan. ${ }^{20}$

Abroad, he had the opportunity to study under Diels, Wilamowitz, and Wölfflin among others. Sinko may be labelled a Hellenist just as well as a Latinist, neo-Latinist or a student of Polish literature. This was also reflected in the careers of his students, whose academic interests often went beyond antiquity. Latin literature was the primary field of his research. He scrutinized the works of such authors as Plautus, Terence, Virgil, Horace, Petronius, and Apuleius. The last name in particular was highly regarded among the academia. ${ }^{21}$ Sinko's pedagogical interest gave rise to a series of Latin language handbooks. ${ }^{22}$

As regards his contribution to the development of Greek literature and language studies, it must be noted that it was Sinko that authored a monumental synthesis of the history of Greek literature (ca. 3000 pages in six volumes), which still remains a canonical work, with only some of its content now outdated due to new discoveries and research progress. In the individual works on Greek literature, he focused on Homer (including the so-called Homeric Question), Hesiod, Greek historians, Euripides and Menander, Alexandrian poetry (especially Callimachus, Theocritus, Lycophron), Plutarch, and Lucian, as well as Ancient Greek

Madyda 1964: 80.

Turasiewicz 2000a: 256-257.

Madyda 1964: 81.

Turasiewicz 2000a: 257.

Turasiewicz 2000a: 257. 
romance and the genesis of drama. He was one of the scholars who continued Sternbach's endeavours to publish a critical edition of Gregory of Nazianzus' works. The most valuable treatises he authored regarding St Gregory are De traditione orationum Gregorii Nazianzeni, pars I: De traditione directa, and pars II: De traditione indirecta. ${ }^{23}$ In his research, Sinko, famous for his extraordinary memory, included almost every single important author in the period between Homer and the writers of the $5^{\text {th }}$ century CE. It is therefore not an easy task to point to the authors who he could have considered particularly worthy of research. For the purposes of illustration, it may be noted that Sinko explored the historiosophical thought in the work of Herodotus, or the method Thucydides employed in the use of sources, as well as the chronology of Xenophon's works. He also studied the chronology of works by Lucian and Plutarch. Among Sinko's works, there are not only thorough, analytical studies of specific issues, but also panoramic overviews from a historical-literary perspective. Classical education combined with Polish studies gave rise to a whole range of works discussing classical inspiration in Polish writers of various periods, from the humanism of the Renaissance, through Romanticism and the $20^{\text {th }}$ century. It is also worth mentioning the study on the reception of ancient ideas in the contemporary civilization, e.g. in such works as Od filantropii do humanizmu i humanitaryzmu [From philanthropy to humanism and humanitarianism] or Posag Europy i jego losy [European heritage and its fate].

Another student of professors Morawski, Miodoński and Sternbach was Seweryn Hammer (1883-1955). In his first academic treatise from 1905, entitled Contumeliae, quae in Ciceronis invectivis et epistulis occurrunt, quatenus Plautinum redoleant sermonem, he "compared the insults used by Cicero in his invectives and letters with the vivid and pungent language used by Plautus and other authors (...)". ${ }^{24}$ As to his contribution to Hellenic studies, Hammer began his scholarly work by participating in a project aiming to publish the works of St Gregory of Nazianzus. During his scholarly visits in Vienna (1907-1909), Milan, Rome and Patmos (1912-1913) and Munich (1913-1914), he was collecting manuscripts of the Saint's writings, and by that he continued

23 Turasiewicz 2000a: 255.

24 Brożek 2000: 302. 
the endeavours of Sternbach and Sinko. ${ }^{25}$ Under the auspices of August Heisenberg in Munich, Hammer became interested in Byzantine folk poetry, which resulted in his treatise De rerum naturae sensu apud poetas medii aevi Graeco-barbaros, on the basis of which he received his Ph.D. at the Jagiellonian University in 1918. After twenty years of teaching, with many scholarships abroad in the meantime, he took over the position of the Head of the Department in 1925, upon the death of professor Morawski. In his studies he worked on Tacitus, Seneca and Virgil, and eventually translated all the works of the latter (however, they have not been published). ${ }^{26}$ Unfortunately, he did not manage to complete the translation of Polibius' works. ${ }^{27}$ He lectured on the history of Latin literature (mainly until the $2^{\text {nd }}$ century). Being proficient in the language of Romans, he also taught a course in Latin stylistics. In the area of Latin literature, he was mainly interested in Apuleius and Tacitus. During World War II, he was arrested by Germans along with a group of professors from Kraków in the Sonderaktion Krakau on 6 November 1939, and until 8 February 1940 he was imprisoned in Sachsenhausen KC. After his return, he engaged in underground teaching from 1943 until the end of occupation. ${ }^{28}$ Even without access to libraries he continued his scholarly work. After the war, he managed to publish selected Greek short stories (1950) and Histories by Herodotus in Polish (1954). He translated all the works of Tacitus, which is generally concerned his greatest achievement as a philologist. ${ }^{29}$

\section{DEVELOPMENT OF THE SCHOOL OF GREEK LITERATURE AND LANGUAGE - HELLENISTS FROM THE LATE $19^{\mathrm{TH}}$ AND EARLY 20 ${ }^{\mathrm{TH}}$ CENTURY}

A person that needs to be mentioned when outlining the development of research on Greek literature is the outstanding Hellenist, Leon Sternbach (1864-1940). Before he became an associate professor at the

Skimina 1990: 262.

Madyda 1964: 65.

Brożek 2000: 305.

Baczkowska 1989b: 163.

Baczkowska 1989b: 163; Skimina 1990: 263. 
Department of Classical Philology at the Jagiellonian University, he had studied in Leipzig, Dresden and in Vienna, under such remarkable scholars, as O. Ribbeck and W. Hartl, whom he considered his masters at that time. His doctoral thesis, entitled Meletemata Graeca and published at the University of Vienna in 1886, attracted the attention of classical philologists internationally. ${ }^{30}$ It was a study on the epigrams collected in the Palatine Anthology. At this point, it is worth mentioning that its new critical edition was prepared by Sternbach himself, despite his young age. In his thesis, he provided a critical analysis and exegesis of the epigrams and explained the fragments which alluded to Greek poetry, from the Homeric times through Byzantine period. Eventually, he specialized primarily in the studies on Byzantine manuscripts and literature, to the point where he was considered the most outstanding researcher of Byzantine literature in the world, beside Krumbacher. ${ }^{31}$ Other fields of his research include gnomology, works of Menander and Aesop, as well as Gregory of Nazianzus's poetry. He published a number of critical editions of ancient texts, but the most important work was a compilation of poems by St Gregory (over 18,000 poems, which required him to compare several hundred manuscripts), an astounding proof of meticulousness. Unfortunately, he did not complete that work, leaving it for his students to finish. The Byzantine authors whose works Sternbach published and explained include Michael Psellos, Georgios of Pisidia, Constantine Manasses, Eugenius of Palermo, Callicles, and Joannes Geometres. His findings often significantly changed or complemented German publications, mainly owing to the discovery of manuscripts unknown to German publishers, which is how he gained international recognition. ${ }^{32} \mathrm{He}$ began his work at the Jagiellonian University in 1891, after receiving his postdoctoral qualification in Lviv, before reaching the age of 30 . He also cooperated with the German magazine Geschichte der byzantynischen Literatur. Not only the academia appreciated his merits. In Rome, he met the Italian king Victor Emmanuel III, and Achille Ratti, later known as Pope Pius XI. ${ }^{33}$ He was friends with celebrated Polish artists, such as Adam Asnyk and Stanisław Wyspiański. A list of his scholarly works

$30 \quad$ Korus 2000b: 176.

31 Korus 2000b: 177.

32 Korus 2000b: 179-181.

33 Korus 2000b: 179-181. 
until 1933 can be found in the volume of Eos issued that year, which was dedicated to him on the $40^{\text {th }}$ anniversary of his professorship. Leon Sternbach, a Polish scholar and patriot of Jewish descent, was arrested by Germans during the Sonderaktion Krakau on 6 November 1939, along with many other professors of the Jagiellonian University. He was transported to the concentration camp in Sachsenhausen and because of his descent was isolated in the Jewish block, where he died 20 II $1940 .^{34}$ After Sternbach, several Polish researchers published critical editions of classical works, but he proved matchless.

Another outstanding Hellenist was Wincenty Lutosławski (18631954), a philosopher studying primarily the works of Plato in the context of classical philology. His supreme achievement was the invention of the method called stylometry, used for determining the chronology of a given author's works or determining the authorship of anonymous works. This method is based on the analysis of style and linguistic statistics. Lutosławski employed it to build a chronology of Plato's Dialogues in a work written in English, entitled The Origin and Growth of Plato's Logic. With an Account of Plato's Style and of the Chronology of His Writings.

The list of prominent Hellenists would be incomplete without Ryszard Gansiniec (1888-1958). He studied in Austria and Germany, with such distinguished figures as Hermann Diels, Ulrich von Wilamowitz-Moellendorff (who supervised his Ph.D. in 1917, based on the thesis entitled De Agathodaemone), Wilhelm Kroll or Wilhelm Schmidt. His studies went beyond classical philology, covering such fields as theology, religious studies and ethnology. It was only in 1948 that he was appointed the Head of the Department at the Jagiellonian University, having previously worked in other highly esteemed academic centres in the country, such as Poznań, Lviv, or Wrocław for a short period. He fought in both World Wars, initially as a draftee in the Prussian army (as a citizen of Prussia before Poland regained independence), and later as a volunteer in the Polish army. ${ }^{35}$ After the war, he worked briefly at the University of Wrocław and conducted research in Stockholm. Upon his return from Sweden, he settled down in Kraków. His academic works

$34 \quad$ Perkowska 1989: 226.

35 Turasiewicz 2000b: 386-387. 
focused on religion, history of magic, philosophy, and patristics. He authored ca. 40 articles in Pauly-Wissowa Real-Enzyklopädie, mainly on magical knowledge, nomenclature of deities and holidays, as well as divination. ${ }^{36}$ He did not write comprehensive syntheses - not counting the chapters on classical antiquity in Zarys dziejów religii [An outline history of religion] - but focused rather on small-scale, analytical works. In his research in religious studies, he adopted a sociological point of view, derived from Emile Durkheim's school of thought (exemplified in the work Charakter spoteczny świat antycznych [Social character of ancient holidays]), whereas the essence of religion for him was the cult. When it comes to Hellenic literature, he wrote about Homer, the general origins of epic poetry, and the beginnings of drama. He opposed the dominant opinion that tragedy stems from dithyramb, arguing that its beginnings are connected with the initiation ceremony of ephebes, as he concluded from comparing this ritual with the ones of primitive peoples. ${ }^{37}$ However, in the posthumously published Entstehung des Theaters, he presented a new and more accurate vision of the birth of theatre, according to which drama was a development of the musical agon of choirs (not featuring actors). Originally, it had nothing in common with the cult of Dionysus, but that changed after Peisistratos introduced a holiday to honour that god at the same time when an agon occured. Gansiniec proved to have good organisation skills and to be a valuable promoter of knowledge, as he was an editor and founder of several journals devoted to classical philology published in Poland. His inclinations for religious studies were not reflected in the work of next generations of Kraków scholars, hence the exceptional character of his oeuvre at the Jagiellonian University. It is worth adding that Gansiniec is also one of the researchers who studied the Latin literature written in Poland in the Middle Ages and later periods.

Another scholar who deserves special recognition is Stanisław Skimina (1886-1962), a student of Sternbach and Morawski at the Jagiellonian University. His Ph.D. dissertation, devoted to ancient feast traditions, was published in Eos, under the title De moribus legibusque convivalibus antiquorum quae fuerit doctrina. He collected there ancient

\footnotetext{
$36 \quad$ Turasiewicz 2000b: 388 .

37 Turasiewicz 2000b: 392.
} 
literary passages referring to feasts and extracted from them a social code of behaviour and rules of conversation at the table. Skimina is renowned for his exceptional commitment to teaching and promotion of classical teaching. Already as an employee of the university, he did not abandon his work as a gymnasium teacher. ${ }^{38}$ Soon after the World War II began, he was among the professors arrested in Sonderaktion Krakau on 6 November 1939. ${ }^{39}$ After he was released from the concentration camp in Sachsenhausen on 8 February 1940, he was engaged in underground teaching. After the war, he proved to have excellent organisation skills, holding high-ranking posts in the Polish Society of Philology. His scholarly research focused on the function of rhythm in Greek prose, whereas his postdoctoral thesis focused in particular on rhythm in the works of John Chrysostom - De Ioannis Chrysostomi rhytmo oratorio (1927). This treatise attracted attention of scholars abroad because no one had examined Chrysostom's works to such a degree before Skimina. ${ }^{40}$ On the basis of the material collected in Greece, Italy, France, and Germany, he published a work in two parts, entitled Etat actuel des études sur le rythme de la prose grecque (Pars II in 1930, Pars I in 1937, sic!). He claimed in it that the rhythm of prose can be used as a criterion to assess the authenticity of words of ancient authors and the chronology of texts. Skimina also made an attempt to simplify the method of examining rhythm of Greek prose, which he found a very burning question - he explained his propositions in the work Comment étudier les clausules dans la prose métrique grecque (Eos, 1934). ${ }^{41}$ Moreover, Skimina studied the metrics of Gregory of Nazianzus (De Gregorii Nazianzeni sermonum proprietatibus, Acta II Congressus Philologorum Slavorum, 1931). This field brought him international acclaim, as he was regarded an authority on a global scale and numerous researchers used the methods he had developed. ${ }^{42}$ Apart from classical studies, Skimina examined Polish-Latin literature and the Polish humanism, especially authors like Jan Dantyszek and Maciej Kazimierz Sarbiewski. He published critical editions of their works.

\footnotetext{
Swoboda 1963: 237-238.

Baczkowska 1989c: 221.

Swoboda 1963: 239.

Swoboda 1963: 240.

Korpanty 2000a: 357.
} 
The person that opens the list of of Hellenists born in the $20^{\text {th }}$ century is the outstanding classical philologist Władysław Madyda (19161970). He obtained his Ph.D. just before World War II, on the basis of a work written under Sinko's supervision, entitled De pulchritudine imaginum deorum quid auctores Graeci saec. II p. Chr. n. iudicaverint, devoted to aesthetics. During the German occupation, he participated in underground teaching. As far as it was possible, he continued collecting materials for future research work. When the war was over, he published a voluminous treatise De arte poetica post Aristotelem exculta, wellreceived abroad. ${ }^{43}$ It is a compilation and classification of opinions on the art of poetry expressed by numerous classical authors from various fields. His later studies focus mainly on the style of Greek and Latin authors, as well as the analysis of selected stylistic phenomena. He published articles such as Maksymusa z Tyru myśli o sztuce [Thoughts on art by Maximus of Tyre], articles about Hermogenes' school of style, Über die Voraussetzungen der Hermogenischen Stillehre, as well as treatises regarding certain Latin authors. Among all the stylistic phenomena, the most important for him was metaphor, which he supported with extensive source material in the article Ancient theories of metaphor and their validity at present. He also wrote about harmony of content and form as stipulated by the ancients, or onomastics in the poetry of Homer. His academic interests covered theatre studies as well. In that field, he left behind the handbook Teatr starożytny Grecji i Rzymu [The ancient theatre in Greece and Rome], which was quite popular for a long time. It was undoubtedly under the influence of Sinko that Madyda wrote about the classical models in the history of the Polish medieval chronicler Jan Długosz, or about the influence of antiquity on Polish literature. Beside his purely academic and didactic work, Madyda was an avid translator, who published the third volume of Aristotle's Rhetoric, along with the work On style by Demetrius of Phaleron and The Arrangement of Words by Dionysius of Halicarnassus in the collection Trzy stylistyki greckie [Three types of Greek stylistics]. Apart from that, he also translated the Anabasis by Xenophon and some of Lucian's dialogues. It was his great ambition to translate the works of Cassius Dio, yet before his death he had only issued one out of the three intended volumes.

43 Turasiewicz 2000c: 686. 
The list of deceased researchers of Greek literature and language concludes with Romuald Turasiewicz (1930-2005), a classical philologist who devoted his work primarily to Greek rhetoric and ancient political thought. He is the author of the monograph Życie polityczne w Atenach $V$ i IV w. przed n. e. w ocenie krytycznej wspótczesnych autorów ateńskich [Political life in Athens in the $5^{\text {th }}$ and $4^{\text {th }}$ century BC under critical assessment of contemporary Athenian authors]. His thorough knowledge of Lysias in particular gave rise to the work Życie i twórczość Lizjasza: początki praktyki i teorii retorycznej [The life and work of Lysias: the beginnings of rhetoric practices and theory]. He also published a translation of Lysias' speeches, as well as a translation and study of speeches of Demosthenes. As far as his field of interest is concerned, Turasiewicz to some extent followed in the footsteps of his master, Władysław Madyda, as evidenced in his works, such as Studia nad stylami greckiej prozy artystycznej [Studies on the styles of the Greek artistic prose] or Od ethosu do ethopoii: studia z antycznej terminologii krytycznoliterackiej u Dionizjusza z Halikarnasu [From ethos to ethopoeia: studies on ancient terminology of literary criticism in the works of Dionysius of Halicarnassus], or by the fact that he studied the phenomenon of irony in the ancient authors. Together with Stanisław Stabryła, he also published a selection of antique short stories in Polish, under the title Nowele antyczne [Classical novellas].

\section{LATIN SCHOOL - THE LATINISTS FROM THE TURN OF THE $19^{\text {TH }}$ TO THE $20^{\text {TH }}$ CENTURY}

One of the first outstanding students of Kazimierz Morawski, who evidently belonged to the Latin branch of classical philology, was Adam Stefan Miodoński (1861-1913), a student of classical, Slavic and Polish studies at the Jagiellonian University, and subsequently a lecturer there in the years 1892-1913. Professor Morawski encouraged him to leave the position of lecturer and the seminars he gave in Freiburg in order to become the head of the Classical Philology Department at the Jagiellonian University. ${ }^{44}$ Although he did not avoid the matters of Hellenic

$44 \quad$ Śnieżewski 2000: 149. 
studies, he was much more absorbed in Latin literature and language. ${ }^{45}$ The subject he taught was Roman literature of the $2^{\text {nd }}$ and the $3^{\text {rd }}$ century, whereas during his thesis seminar in Latin, he discussed the works of Polybius, Catullus, Tibullus, Petronius, Apuleius, and others. Another area of his academic interests was historical linguistics (including the historical grammar of Latin and Vulgar Latin). He published his works in scholarly journals. ${ }^{46}$ He gained recognition abroad thanks to his studies on Latin Christian prose-writers. ${ }^{47}$

Some believe that the title of "the greatest Polish Latinist after Kazimierz Morawski" 48 should be given to Gustaw Edward Przychocki (1884-1947). He graduated from philological studies at the Jagiellonian University in 1908, only to receive Ph.D. a year later on the basis of his treatise on the relationship between Ovid's poetry and Greek New Comedy (Ovidiana Pars I. Quae ratio inter Ovidium comoediaeque novae poetas in rebus amatoriis depingendis intercedat, exponatur). He also completed his studies at the universities in Vienna, Berlin and Oxford. From 1918 he was affiliated with the University of Warsaw (a professor in the Department of Classical Philology, Head of the Faculty of Philosophy, Rector and Vice Rector). In 1935 he moved to the Jagiellonian University, where he was Head of the Department of Classical Philology. For many years, at the request of the Polish Academy of Learning, he studied the manuscripts of St George of Nazianzus, which later served as the basis for his postdoctoral dissertation (De Gregorii Nazianzeni epistulis quaestiones selectae) ${ }^{49}$ However, the lion's share of Przychocki's works are devoted to Latin authors, such as Plautus (a voluminous and comprehensive monograph of this author published in 1925, a translation of all tragedies in 1931-1937), Ovid and Seneca (as the one who continued writing Republican tragedies). His scholarly output includes 98 titles.

\footnotetext{
$45 \quad$ Madyda 1964: 58.

46 Hammer 1948: 32.

47 Madyda 1964: 59; he cooperated with the editors of Corpus scriptorum ecclesiasticorum published in Vienna; Śnieżewski 2000: 149.

48 Styka 2000: 311.

49 Hammer 1948: 240-241.
} 
Przychocki was the master and a patron of the next great Latinist, Wladysław Strzelecki (1905-1967). ${ }^{50}$ Having graduated from the Jagiellonian University, Strzelecki continued the classical studies at the University of Warsaw, where he received his Ph.D. on the basis of the treatise De tragicorum Romanorum memoria apud Nonium servata, pars $I$. He was on a scholarship in Berlin as a student of such eminent figures as Eduard Norden and Werner Jaeger. In Göttingen, he worked with Richard Reitzenstein and Eduard Fraenkel. He also studied at the University of St Andrews in Scotland. ${ }^{51}$ The time spent abroad allowed him not only to improve his knowledge in the area of philology, but also to learn new research methods and to build up contacts with many prominent scholars at European universities. Upon his return to Poland, he continued to conduct research at the University of Warsaw, and after the war also at the University of Wrocław. In 1959, he returned to the Jagiellonian University. ${ }^{52}$ Strzelecki's areas of study include Latin prosody, Roman lexicographers and grammarians, as well as Old Latin literature. Among his studies on prosody, one that deserves special mention is his work on Seneca's iambic trimeter (De Senecae trimetro iambico quaestiones selectae), as well one devoted to the importance of metrics in the art of early Roman writers of tragedy (De re metrica tragicorum Romanorum collection quaestiones). His Metryka grecka i łacińska [Greek and Latin prosody] is so far the only Polish handbook on metrics. ${ }^{53}$ Research on lexicographical and grammatical issues gave him international recognition, as can be seen from the cooperation with foreign encyclopaedia publishers (e.g. Der Kleine Pauly. Lexikon der Antike, where he authored a series of entries). ${ }^{54}$ Another great success of his at the international level was the research on Roman epic, as part of which Strzelecki published fragments of a national Roman epic poem by Gnaeus Naevius Belli Punici carmen, with a reconstruction of the content, a new arrangement of the content, as well as a commentary on the prosody. He also intended to prepare a new edition of Tragicorum Romanorum Fragmenta, but unfortunately his premature death prevented him from doing so.

\footnotetext{
50 Stabryła 2000: 606.

$51 \quad$ Stabryła 2000: 606.

52 Stabryła 2000: 607.

53 Stabryła 2000: 609.

54 Stabryła 2000: 609.
} 
Another student of Sinko's, Kazimierz Kumaniecki (1905-1977), although mainly affiliated with the University of Warsaw, was also connected with the Jagiellonian University for a short time. He originally devoted his academic activity to the Hellenistic period and conducted research on the works of Euripides and Aeschylus. Kumaniecki also published a translation of the History of the Peloponnesian War by Thucydides which was to become canonical. Yet he soon began to show an inclination towards the literature of the Golden Age of Rome and later on this topic dominated his studies. In particular Kumaniecki is renowned for his exhaustive studies of Cicero. The first monograph (1959) devoted to this author initiated a series of studies on his life and works, whether preserved or not, including a critical edition of the dialogue De oratore. In this matter, Kumaniecki somehow followed in the footsteps of Morawski (Vol. 2 of Literatura rzymska, [Roman Literature]), although the former's analyses are considered to be more detailed. ${ }^{55}$ Kumaniecki's Literatura rzymska: okres cyceroński [Roman Literature: Ciceronian period], published posthumously, was considered canonical for years to come.

In 1931, another important figure began studying at the university, under such distinguished masters as Hammer, Sinko or Kumaniecki, and that was namely Mieczysław Brożek (1911-2000). He managed to receive his Ph.D. just before World War II, his thesis was titled De Calliae tragoedia grammatica. ${ }^{56}$ Unfortunately, soon after the outbreak of war, he was sent to the Sachsenhausen concentration camp, and later to Dachau, arrested along with other professors of the Jagiellonian University in Sonderaktion Krakau on 6 November 1939. ${ }^{57}$ After his release from Dachau in 15 January 1941, he returned to Kraków and took part in a secret course of classical philology during the German occupation. Right after the War, he came back to his academic career at the Jagiellonian University, starting in 1945 as a junior lecturer. He was the Head of the Latin Unit from 1960 onwards, and became the Head of the Latin Philology Department at the Jagiellonian University in 1967. His scholarly works are mainly devoted to the Roman literature. He was the

\footnotetext{
$55 \quad$ Plezia 1993: 345.

56 Korpanty 2000b: 784.

$57 \quad$ Baczkowska 1989a: 136.
} 
author of the handbook Historia literatury łacińskiej [History of Latin Literature] (1969), which replaced Professor Morawski's work on the same topic. ${ }^{58} \mathrm{He}$ studied and translated such works as the comedies of Terence, Cicero's speeches and dialogues, Lucretius' De rerum natura, and $A b$ urbe condita by Livius. He also examined Latin prosody. ${ }^{59} \mathrm{He}$ was renowned for his beautiful use of Latin, which he employed not only in his academic work, but also in poetry of his own. ${ }^{60}$

Another outstanding medievalist and lexicographer-to-be Marian Plezia (1917-1996) was encouraged to study Classical Philology at the Jagiellonian University by Kazimierz Kumaniecki. During his second year, he already astonished everyone with his treatise De Ciceronis Academicis dissertationes tres, which won him recognition in the academia in Poland and abroad. ${ }^{61} \mathrm{He}$ passed his master's examination before Professor Sinko in 1944, and soon after he passed his doctoral viva. The abovementioned work of his was accepted as his doctoral thesis. ${ }^{62}$ Since 1953, when he began his work as the head of a research centre in the Polish Academy of Learning, he devoted himself to Stownik łacińskopolski [Latin-Polish Dictionary] and Stownik Laciny Średniowiecznej $w$ Polsce [Dictionary of Medieval Latin in Poland]. The latter, still continued today, is "the best known project of the Polish humanities on an international scale". ${ }^{63}$ Plezia's scholarly achievements amount to about 400 publications. Apart from lexicographic works, these include studies on Roman philosophical literature and medieval Latin literature in Poland (approximately 200 publications). ${ }^{64}$

\footnotetext{
Korpanty 2000b: 787.

Korpanty 2000b: 788-789.

Korpanty 2000b: 791.

http://www.ptta.pl/pef/pdf/p/plezia.pdf [on-line: 30.04 .2018 ].

http://www.ptta.pl/pef/pdf/p/plezia.pdf [on-line: 30.04 .2018$]$.

http://scriptores.pl/lexicon/historia-slownika/ [on-line: 30.04.2018].

http://www.ptta.pl/pef/pdf/p/plezia.pdf [on-line: 30.04 .2018 ]
} 


\section{CLASSICAL STUDIES TODAY - CONTEMPORARY RESEARCHERS}

A Hellenist whose entire scholarly career has been connected with the Jagiellonian University is Kazimierz Korus (born 1944), whose main focus has been on the history and theory of Greek literature, with particular regard to satire, drama and mime, e.g. in Mim grecki w gatunkach literackich [Greek mime in literary genres]. He has also studied the ancient theory of teaching and education, which may be seen in such works of his as Nauka i nauczanie w opinii starożytnych Greków (Science and teaching in the opinion of the ancient Greeks), or Program wychowawczy Plutarcha z Cheronei (The educational programme of Plutarch of Chaeronea). Furthermore, his scientific interests include the post-classical period and ancient literary criticism. The fact that Plutarch and Lucian were the object of Korus's several larger studies, may be due to the influence of his university masters, Tadeusz Sinko and Władysław Madyda. Apart from his original works, he translated some of Parallel Lives by Plutarch. Furthermore, he has achievements in promoting classical education: - in 1980 he was one of the initiators of a (still existing) class with an extended programme in classics in the Bartłomiej Nowodworski High School in Kraków, where he himself taught Greek for many years. Together with his wife, he wrote a Greek language handbook Hellenike Glotta.

Among contemporary Latinists, it is worth mentioning the editor of a Latin-Polish academic dictionary, Józef Korpanty (born 1941). His scholarly achievements comprise numerous articles, translations (including Cicero's Laelius sive de amicitia), treatises, including The development of the political role of a unit in the Roman Republic and its reflection in the literature, presenting "(...) the political thought of such authors, as Gnaeus Naevius, Cato the Elder, Plautus, older annalists, Ennius, Scipio Africanus the Younger together with his social milieu, Pacuvius, Lucius Accius, Gaius Luciulius, the Gracchi brothers, younger annalists, Marius, Sulla, Pompey, Caesar, Cicero, Sallust, Virgil and Horace". ${ }^{65}$ Another important work of his, Study on the Latin politicalsocial terminology in the period of the Republic of Rome, focuses on

$65 \quad$ Śnieżewski 2011: 21. 
explaining the meaning of the "Virtus Romana", which defines the ideal Roman citizen. ${ }^{66}$ Korpanty's most important publication is said to be Lukrecjusz. Rzymski apostol epikureizmu [Lucretius. The Roman apostle of Epicureanism], ${ }^{67}$ in which Polish readers can familiarise themselves with the message of the poem De rerum natura. As for the abovementioned Latin-Polish dictionary, it should be noted that "the dictionary entries were edited according to the latest methods of applied linguistics (in the area of lexicography), contrastive linguistics (translation studies) and foreign language teaching." ${ }^{68}$ Professor Korpanty is the author of the majority of entries in the dictionary.

Another outstanding scholar well versed in Latin literature and language is Professor Stanisław Stabryła, born in 1936 in Lviv. After graduating in philology from the Jagiellonian University, Stabryła became an associate professor there in 1976. The scope of his research comprises Roman and Christian literature, classical literary theory, as well as the perception of classical antiquity in Polish literature. ${ }^{69}$ His publications include studies on Ovid and Virgil, with the first one being Latin Tragedy in Virgil's Poetry published in 1970, his important habilitation thesis Funkcja noweli w strukturze gatunków literatury rzymskiej [Function of a novel in the structure of Roman literary genres] as well as numerous popular science publications in philological magazines, with many devoted to Prudentius, such as Wybrane problemy "Peristephanon" Prudencjusza [Selected problems of Prudentius" "Peristephanon"]; "Dzieje Apostolskie" w poezji Prudencjusza ["Acts of the Apostles" in the poetry of Prudentius]; Pagan and Christian Rome in Prudentius' "Peristephanon"; Historia rzymska w "Pieśniach" Horacego [Roman history in Horace's "Odes"]; Kaligula $w$ dramacie i historii [Caligula in drama and history]; Antyk $w$ dramacie historycznym [Antiquity in historical drama]; Polskie Antygony XX wieku [Polish Antigones of the $20^{\text {th }}$ century]; Funkcje antyku we współczesnej szkole [Functions of antiquity in contemporary school]; Wielki humanista? Tadeusz Sinko (A great humanist? Tadeusz Sinko), as well as works on the antique culture and mythology, such as Zarys kultury starożytnej Grecji i Rzymu (Cultural

\footnotetext{
66 Śnieżewski 2011: 21.

67 Śnieżewski 2011: 25.

68 Śnieżewski 2011: 28.

69 www.stabryla.pl [on-line: 30.04.2018].
} 
outline of the ancient Greece and Rome); Mały leksykon mitologii greckiej i rzymskiej [Small lexicon of Roman and Greek mythology]; Mitologia grecka i rzymska. Stownik [Greek and Roman mythology. A glossary]. Total number of publications authored by Professor Stabryła amounts to ca. 200 items.

The research activities of the authors described above, amazingly thorough and extensive, may nowadays induce a sense of duty, compelling us to continue this impressive legacy. However obvious and indisputable the necessity to raise awareness about antiquity may be, we should make every effort to continue to enhance and develop the achievements of those great classical philologists.

Looking at any work of the scholars named above, one might notice certain analogies with respect to their scope. Especially noteworthy are studies on Gregory of Nazianzus' works (examined by Leon Sternbach, Tadeusz Sinko, Seweryn Hammer, Stanisław Skimina, and Gustaw Edward Przychocki), conducted regularly due to a decision of the Academy of Learning in 1905 to issue the works of the Church Fathers, mainly those from the $4^{\text {th }}$ century. This was an initiative of the great patron of all classical philologists, the famous Ulrich Wilamowitz. Among the recurring topics one should also add research on ancient rhetoric (Kazimierz Morawski and Romuald Turasiewicz), issues related to ancient stylistics (Wincenty Lutosławski and Władysław Madyda) or Greek and Latin prosody (Władysław Strzelecki and Mieczysław Brożek). A number of scholars also dealt with ancient theatre (including Ryszard Gansiniec and Władysław Madyda) and issues of theory of ancient literature (Kazimierz Korus, Stanisław Stabryła).

An important aspect of the development of classical philology in Poland was research on ancient lexicographers and grammars (Władysław Strzelecki) and the development of linguistics (Adam Stefan Miodoński). Lexicographic research was conducted by Marian Plezia and Józef Korpanty.

Each of the academic scholars mentioned above also undertook the effort of translating the works of particular antique authors. Due to their multitude, it is not possible to list all of them here, but the translations included works by Virgil and Herodotus (Seweryn Hammer), John 
Chrysostom (Stanisław Skimina), Plautus, Ovid and Seneca (Gustaw Edward Przychocki), Thucydides (Kazimierz Kumaniecki), Terence and Cicero (Mieczysław Brożek) and Lucretius (Józef Korpanty).

It is worth emphasising that Polish classical philologists were involved in teaching activities and had a continuous sense of pedagogical mission, which often filled their students with admiration and appreciation. Also in the difficult times of occupation during Second World War, most of the scholars under discussion took part in secret teaching, and continued their research even though they did not have access to libraries.

Their devotion to teaching is also reflected in number of published handbooks in the field of classical philology. Starting from the monumental The History of Roman Literature written by Kazimierz Morawski, or a six-volume synthesis of the History of Greek Literature by Tadeusz Sinko, and ending with a textbook on Greek and Latin Prosody by Władysław Strzelecki, or Roman Literature: Cicero's period by Kazimierz Kumaniecki. Another great achievement was a handbook on the History of Latin Literature by Mieczysław Brożek, and finally the publication of a textbook of the Greek language, Hellenike glotta, by Kazimierz Korus (co-authored with his wife).

As mentioned in the introduction, the biographies presented above, demonstrate that the scholars under discussion did not limit themselves to one discipline only, regardless of whether their main focus was on Greek or Latin literature and language.

\section{REFERENCES}

Baczkowska W., 1989a, 'Mieczysław Brożek', [in:] Wyrok na Uniwersytet Jagielloński 6 listopada 1939, L. Hajdukiewicz (ed.), Kraków, pp. 135-136.

Baczkowska W., 1989b, 'Seweryn Hammer (1883-1955)', [in:] Wyrok na Uniwersytet Jagielloński 6 listopada 1939, L. Hajdukiewicz (ed.), Kraków, pp. 162-163.

Baczkowska W., 1989c, 'Stanisław Skimina (1886-1962)', [in:] Wyrok na Uniwersytet Jagielloński 6 listopada 1939, L. Hajdukiewicz (ed.), Kraków, pp. 221-222. 
Brożek M., 2000, 'Seweryn Hammer (1883-1955)', [in:] Uniwersytet Jagielloński. Złota Księga Wydziału Filologicznego, J. Michalik, W. Walecki (eds.), Kraków, pp. 301-306.

Gruchała J.S., 2000, 'Philologia perennis. Tradycje badań filologicznych w Akademii Krakowskiej do początków XIX wieku’, [in:] Uniwersytet Jagielloński. Złota Księa Wydziału Filologicznego, J. Michalik, W. Walecki (eds.), Kraków, pp. 9-33.

Hammer S., 1948, Historia filologii klasycznej w Polsce, Kraków.

Korpanty J., 2000a, 'Stanisław Skimina (1886-1962)', [in:] Uniwersytet Jagielloński. Złota Księga Wydziału Filologicznego, J. Michalik, W. Walecki (eds.), Kraków, pp. 355-359.

Korpanty J., 2000b, 'Mieczysław Brożek (1911-2000)', [in:] Uniwersytet Jagielloński. Złota Księga Wydziału Filologicznego, J. Michalik, W. Walecki (eds.), Kraków, pp. 783-792.

Korus K., 2000a, 'Kazimierz Morawski (1852-1925)', [in:] Uniwersytet Jagielloński. Złota Ksiega Wydziału Filologicznego, J. Michalik, W. Walecki (eds.), Kraków, pp. 117-126.

Korus K., 2000b, 'Leon Sternbach (1864-1940)', [in:] Uniwersytet Jagielloński. Zlota Księga Wydziału Filologicznego, J. Michalik, W. Walecki (eds.), Kraków, pp. 175-185.

Madyda W., 1964, Z dziejów filologii klasycznej na Uniwersytecie Jagiellońskim, Kraków.

Perkowska U., 1989, 'Leon Sternbach (1864-1940)', [in:] Wyrok na Uniwersytet Jagielloński 6 listopada 1939, L. Hajdukiewicz (ed.), Kraków, pp. 225-226.

Plezia M., 1966, 'Dzieje filologii klasycznej w Polsce od początku XVII do początku XX w.', Studia i Materiały z Dziejów Nauki Polskiej, Seria A, z. 9.

Plezia M., 1993, Z dziejów filologii klasycznej w Polsce, Warszawa.

Skimina S., 1990 (rpt.), 'Hammer Seweryn (1883-1955)', [in:] Polski słownik biograficzny, T. IX, K. Lepszy et al. (eds.), 1960-1961, Wrocław-WarszawaKraków, pp. 262-263.

Sondel J., 2012, Słownik historii i tradycji Uniwersytetu Jagiellońskiego, Kraków. Stabryła S., 2000, ‘Władysław Strzelecki (1905-1967)', [in:] Uniwersytet Jagielloński. Złota Księga Wydziału Filologicznego, J. Michalik, W. Walecki (eds.), Kraków, pp. 605-612.

Styka J., 2000, 'Gustaw Przychocki (1884-1947)', [in:] Uniwersytet Jagielloński. Złota Księga Wydziału Filologicznego, J. Michalik, W. Walecki (eds.), Kraków, pp. 307-313. 
Swoboda M., 1963, ‘Stanisław Skimina (1886-1962)’, Eos 53, pp. 237-253.

Śnieżewski S., 2000, ‘Adam Stefan Miodoński (1861-1913)’, [in:] Uniwersytet Jagielloński. Złota Księga Wydziału Filologicznego, J. Michalik, W. Walecki (eds.), Kraków, pp. 147-153.

Śnieżewski S., 2011, ‘Józef Korpanty - filolog klasyczny i jego dzieło', Classica Cracoviensia 14, pp. 19-32.

Turasiewicz R., 2000a, 'Tadeusz Sinko (1877-1966)', [in:] Uniwersytet Jagielloński. Złota Księga Wydziału Filologicznego, J. Michalik, W. Walecki (eds.), Kraków, pp. 253-266.

Turasiewicz R., 2000b, 'Ryszard Gansiniec (1888-1958)', [in:] Uniwersytet Jagielloński. Złota Księga Wydziatu Filologicznego, J. Michalik, W. Walecki (eds.), Kraków, pp. 385-397.

Turasiewicz R., 2000c, 'Władysław Madyda (1916-1970)', [in:] Uniwersytet Jagielloński. Złota Księga Wydziału Filologicznego, J. Michalik, W. Walecki (eds.), Kraków, pp. 685-690.

http://www.ptta.pl/pef/pdf/p/plezia.pdf [on-line: 30.04.2018].

http://scriptores.pl/lexicon/historia-slownika/ [on-line: 30.04.2018].

www.stabryla.pl [on-line: 30.04.2018]. 